\title{
PKMS Peningkatan Keterampilan Kelompok Ibu-Ibu Orangtua Murid SD Muhammadiyah Pulo Brayan
}

\author{
Zubaidah Hanum ${ }^{1,}{ }^{*}$, Iswandi Idris ${ }^{2}$, Neni Triastuti ${ }^{1}$, Ruri Aditya Sari ${ }^{1}$ \\ ${ }^{1}$ Administrasi Bisnis, Politeknik LP3I Medan, Medan, Indonesia \\ 2 Teknik Komputer, Politeknik LP3I Medan, Medan, Indonesia \\ Email: 1, ${ }^{*}$ hanum2011@gmail.com
}

\begin{abstract}
Abstrak-Mitra Sasaran PKMS adalah kelompok masyarakat dengan jenis mitra non produktif yaitu ibu-ibu oragtua murid SD kelas 1 yang dipimpin oleh Ibu Dian Novita jumlah anggaota ada 40 orangtua murid. Permasalahan mitra merasa bosan, cemas menghadapi situasi pandemi covid-19 dan belum menemukan produk yang dapat dijual dimasa pandemi covid-19 serta cara memasarkannya Pelaksanaan pelatihan dilakukan baik secara teori maupun praktek dengan nara sumber yang ahli dibidangnya melalui tanya jawab, diskusi dan Latihan. Indikator keberhasilan PKMS adalah adanya publikasi di jurnal Nasional, Publikasi media cetak, video pelaksanaan kegiatan, peningkatan keberdayaan mitra berupa peningkatan pengetahuan, keterampilan dan pendapatan.mitra. Lokasi mitra berjarak $10 \mathrm{~km}$ dari kampus Politeknik LP3i Medan yaitu di jalan Cemara gang Nangka Pulo Brayan. Hasil PKMS menunjukkan peningkatan pengetahuan dan keterampilan, mitra. Mitra bisa meminimkan rasa bosan dengan mengikuti pelatihan motivasi, pengetahuan tentang bisnis, Pelatihan membuat masker kain dan menggunakan media sosial untuk menjual hasil keterampilan maupun menjadi reseller.
\end{abstract}

Kata Kunci: PKMS; Masker Kain; Pandemi Covid-19; Pelatihan; Bisnis

\begin{abstract}
The target partners of PKMS are community groups with non-productive types of partners, namely parents of first grade elementary school students led by Mrs. Dian Novita with a total of 40 parents. The problem of partners feeling bored, anxious about the covid-19 pandemic situation and has not found products that can be sold during the covid-19 pandemic and how to market them. The training is carried out both in theory and practice with resource persons who are experts in their fields through questions and answers, discussions and exercises. PKMS success indicators are publications in national journals, media mass publications, video implementation of activities, increasing partner empowerment in the form of increasing knowledge, skills and income. The partner location is $10 \mathrm{~km}$ from Politeknik LP3I Medan, namely on Jalan Cemara Gang Nangka Pulo Brayan. The results of PKMS show an increase in knowledge and skills, partners. Partners can minimize boredom by participating in motivational training, business knowledge, training to make cloth masks and using social media to sell skills or become resellers.
\end{abstract}

Keywords: PKMS; Cloth Mask; Covid-19 Pandemic; Business Training

\section{PENDAHULUAN}

Presiden Republik Indonesia, Joko Widodo mengumumkan bahwa virus covid-19 telah masuk di Indonesia pada bulan Maret 2020 dan himbauan untuk tidak berada di luar rumah, bekerja dari rumah, belajar dari rumah serta memberlakukan pembatasan sosial berskala besar (PSBB) bagi daerah yang memiliki mobilitas tinggi (Ansori, 2020). Dengan adanya kebijakan dari pemerintah untuk belajar dari rumah, bekerja dari rumah maka peran keluarga sangat penting. Pandemi covid-19 hingga sekarang belum juga berakhir sehingga dampak kegiatan yang dilakukan terbatas hanya dirumah saja bisa menimbulkan kebosanan. Saat ini rumah menjadi pusat kegiatan bagi semua anggota keluarga, Hal ini bisa menjadi positif karena pusat kegiatan kembali keasalnya, yaitu rumah. Tapi jika semua kegiatan hanya dilakukan dirumah saja, juga berdampak menimbulkan psikosomatis, yaitu ganguan fisik yang disebabkan oleh faktor kejiwaan dan tumpukan emosi yang dapat menimbulkan guncangan dalam diri seseorang di masyarakat, seperti kecemasan, stress, lingkungan sosial yang banyak mempengaruhi pikiran negarif, seperti berita hoax dan sebagainya (T.N.I, 2020).

Dampak covid-19 ini juga menyebabkan turunya daya beli masyarakat khususnya golongan yang berpendapatan rendah dan bahkan ada pekerja yang dirumahkan dan di PHK (Hanoatubun, 2020) Penerapan kebijakan menjaga jarak atau karantina wilayah maupun pembatasan jarak antara manusia menyebabkan dampak ekonomi yang signifikan terhadap berbagai industri terutama manufaktur, pariwisata, perhotelan, transportasi dan lainnya (Sari, 2021). Wanita diberikan kesempatan untuk berperan ganda yaitu sebagai ibu rumah tangga dan wanita karir, namun dalam kehidupan bermasyarakat masih banyak yang tidak memanfaatkan kesempatan ini. Kebanyakan aktivitas wanita yang sudah menikah adalah mengantar dan menjeput anak-anaknya pergi dan pulang sekolah, mengikuti arisan dan kegiatan lainya. Walaupun keputusan sebagian wanita yang sudah menikah memilih untuk tidak bekerja masih ada upaya yang dapat dilakukan untuk meningkatkan kesejahteraan hidup dan membantu perkembangan perekonomian rumahtangganya (Laelisneni, 2020).

Adapun upaya yang dapat dilakukan adalah dengan mendidik wanita menjadi wirausaha. Dalam hal ini keputusan wanita yang menjadi wirausahan terdapat faktor-faktor dalam diri sendiri/ internal dan faktor-faktor eksternal. Faktor internal antara lain : Minat, motivasi, pemberdayaan diri, sedangkan faktor eksternal antara lain: Lingkungan keluarga, dukungan suami/keluarga, sumber modal, lingkungan sosial (Prstiana, 2009). SD Muhammadiyah 28 merupakan Sekolah Dasar yang berlokasi di jalan Cemara Gang Nangka P. Brayan. Sekolah ini 
memiliki murid sebanyak 40 orang khusus kelas 1 SD yang muridnya berusia 7 tahun, semenjak pandemi covid19 kegiatan sekolah tidak berjalan seperti biasa dan bahkan sampai sekolah ditutup.

Berdasarkan pengamatan peneliti diperoleh bahwa murid tetap belajar namun dilaksanakan secara daring sehingga para orangtua murid diberi grup kelas untuk memantau perkembangan sekolah anaknya. Setiap hari guru memberi pelajaran dan tugas melalui WA. Orangtua murid harus terus mendampingi anaknya selama proses pembelajaran karena murid masih berumur 7 tahun jadi belum paham tugas yang akan dikerjakan. Ibu rumah tangga selain mengerjakan tugas rumah ditambah dengan tugas-tugas sekolah anak- anaknya dan harus berada dirumah saja sedangkan pendapatan keluarga berkurang karena dampak pandemi covid-19. Selanjutnya ibu-ibu orangtua murid merasa bosan, cemas dan tertekan sehingga terjadi tumpukan emosi menghadapi situasi pandemi covid-19. Hal ini disebabkan karena ketidak mampuannya serta himbauan untuk tidak berada di luar rumah, bekerja dari rumah, serta memberlakukan pembatasan sosial berskala besar sehingga mitra tidak bisa menyalurkan kegiatannya seperti shopping, rekreasi, arisan dan kegiatan lainnya. Mitra ingin membantu keluarga dalam penambahan income namun tidak memiliki kemampuan tentang bisnis dan kurang paham tentang produk yang bisa dijual dan bagaimana cara menjualnya di masa pandemi covid-19 ini.

\section{METODE PELAKSANAAN}

Pelatihan dilakukan baik secara teori maupun praktek dengan narasumber, yaitu Ketua pelaksana PKMS yaitu Zubaidah Hanum, SE.,MM seorang yang pakar dibidang Pemasaran, dan didampingi oleh Iswandi Idris, ST.,MT yang pakar dibidang Bisnis digital serta anggota Neni Triastuti, SPi.,M.Psi seorang yang pakar dibidang psikologi. Materi yang diberikan adalah Pelatihan tentang bisnis, pelatihan motivasi dan kreativitas, pelatihan membuat masker kain dan pelatihan pemasaranya melalui media online. Metode pelaksanaan Pelatihan tentang Bisnis dan sosialisasi pengenalan bisnis reseller kepada peserta sehingga peserta dapat mencari distributor dan produk untuk dijual dan fokus branding, toko dan tetap menjaga kualitas layanan toko tersebut. Pelatihan ini disampaikan secara teori dilakukan 2 kali tatap muka teori dan 2 kali tatap muka praktek. Metode pelatihan yang digunakan adalah ceramah, tanya jawab, Latihan atau praktek langsung menggunakan Handphone. Pelatihan diharapkan dapat meningkatkan pemahanan peserta dalam menjalankan sebuah bisnis. Pelatihan kedua yaitu Motivasi dan kreativitas yang diberikan untuk mengurangi rasa bosan, cemas dalam masa pandemi covid-19. Dilakukan sharing dan tanya jawab terkait kegiatan dan hobby yang dimiliki serta memberikan arahan untuk lebih kreatif lagi oleh narasumber yang ahli dibidang psikologi. Dalam pelatihan diberikan wawasan penanganan kegiatan selama pandemi covid-19, menghibur diri sendiri dengan melakukan hobby ( memasak, membuat kue, menanam bunga) dan kegiatan lainya yang bisa menambah pendapatan dengan melakukan penjualan di media sosial. Pelatihan ini disampaikan secara teori dilakukan 2 kali tatap muka. Pelatihan ketiga yaitu membuat masker kain tanpa mesin jahit. Pelatihan dengan metode ceramah dan praktek sebanyak 4 kali pertemuan. Pelatihan disampaikan oleh Narasumber Siska Hasibuan., S.Sos.,M.Pd orang yang ahli dibidang bisnis. Alat dan bahan yang dibutuhkan adalah kain katun, jarum jahit, benang, jarum pentol, gunting, seterika, karet/tali. Lankah-langkah pembuatan masker yaitu ukur bahan kain P $18 \mathrm{~cm}$ L $20 \mathrm{~cm}$ lalu gunting dan buat sebanyak 3 lapis. Selanjutnya satukan kain yang sudah digunting, kemudian sisakan $1 \mathrm{~cm}$ dibagian atas dan bawah kemudian lipat dan jahit jelujur. Selesaikan bagian kiri dan kanan jahit jelujur seperti diatas, lalu siapkan karet/tali sepanjang $20 \mathrm{~cm}$ kemudian masukkan tali tersebut kedalam lubang lipatan kain menggunakan jarum besar/peniti. Setelah terpasang jahit menjadi satu dan lakukan dikedua sisi. Kemudian seterika lipatan masker supaya hasil lebih baik dan rapi. Pelatihan diharapkan dapat menambah dan meningkatkan keterampilan peserta dalam membuat masker dari kain tanpa dijahit dan dapat dimanfaatkan oleh keluarga dan dapat dijual untuk menambah pendapatan. Pelatihan keempat yaitu pemasaran secara online dilakukan secara daring dengan mengirimkan video pelatihan di grup peserta. Pelaksanaan tidak bisa dilaksanakan secara tatap muka karena kondisi di wilayah Medan pemberlakuan pembatasan kegiatan masyarakat. Pelatihan menerangkan fitur-fitur aplikasi, mengambil gambar produk dan Menyusun gambar sehingga tertata dengan baik dan menarik. Pelatihan diharapkan dapat menambah pengetahuan peserta sehingga dapat memanfaatkan media sosial dengan bijak.

\section{HASIL DAN PEMBAHASAN}

Pemberian motivasi kepada ibu-ibu orang tua murid yang dapat mengurangi rasa bosan, cemas terhadap situasi pandemi covid-19 dan menimbulkan kreativitas untuk melihat potensi yang ada di diri mereka. Peserta yang semuanya terdiri dari ibu-ibu orangtua murid SD memiliki kemampuan dalam masak-memasak, membuat kue dan semuanya memiliki sosial media seperti facebook dan Instagram, namun belum dapat memanfaatkan media sosial dengan bijak. Hasil dari pelatihan pemasaran online ini dapat dilihat dari media sosial para peserta PKMS yang mulai mengisinya dengan promosi penjualan hasil kreativitas masakan peserta juga mulai pandai mempromosikan produk lainnya seperti pakaian, masker, aksesoris dan lainnya. Pelatihan Penggunaan ECommerce Sebagai Upaya Pemasaran Penjualan Produk Kerajinan Rumah Tangga Ibu-ibu PKK ini merupakan 


\section{Journal of Social Responsibility Projects by Higher Education Forum}

Vol 2, No 2, November 2021, Page 87-90

ISSN 2723-1674 (Media Online)

pilihan yang tepat untuk mengatasi permasalahan jangkauan area pemasaran yang masih terbatas, produk yang tidak dapat terjual dengan cepat dan kurangnya pemanfaatan teknologi secara maksimal (Siagian, 2021).

Dalam pelaksanaan program ini, iptek yang diimplementasikan mitra yakni untuk mengatasi permasalahan mengenai minimnya kemampuan ibu-ibu orangtua murid dalam berbisnis untuk membantu ekonomi keluarga selama pandemi covid-19. Mitra telah diberikan pelatihan tentang bisnis, memberikan solusi menjadi pembisnis tanpa modal yaitu dengan menjadi reseller, diberi pelatihan membuat masker dari kain yang dapat dijual dan digunakan sendiri untuk menjaga kesehatan dan terhindar dari pandemi covid-19. Mitra juga diberikan pelatihan pemasaran secara elektronik atau e-marketing menggunakan media sosial facebook, istagram sehingga mitra mampu melakukan bisnis menggunakan teknologi. Pelatihan ini dilakukan dengan cara ceramah, tanya jawab, diskusi dan simulasi. Pelatihan dan kegiatan ini dapat mengurangi rasa bosan, kecemasan ibu-ibu orangtua murid karena dapat menggunakan media sosial dengan hal-hal yang bermanfaat dan menghasilkan tambahan. Mitra bisa mengembangkan bisnisnya dengan menjual hasil karya seperti masakan rumahan, bubur, kue dan lainnya dengan menggunakan media sosial facebook dan instagram karena dimasa pandemi ini banyak sekali orang yang mencari masakan cepat saji, alat-alat pelindung seperti masker, vitamin. Ini merupakan peluang usaha yang dapat dimanfaatkan oleh mitra karena sudah diberi pelatihan tentang pemasaran dengan menggunan teknologi. Gambar berikut ini merupakan kegiatan pelatihan yang diberikan kepada peserta:

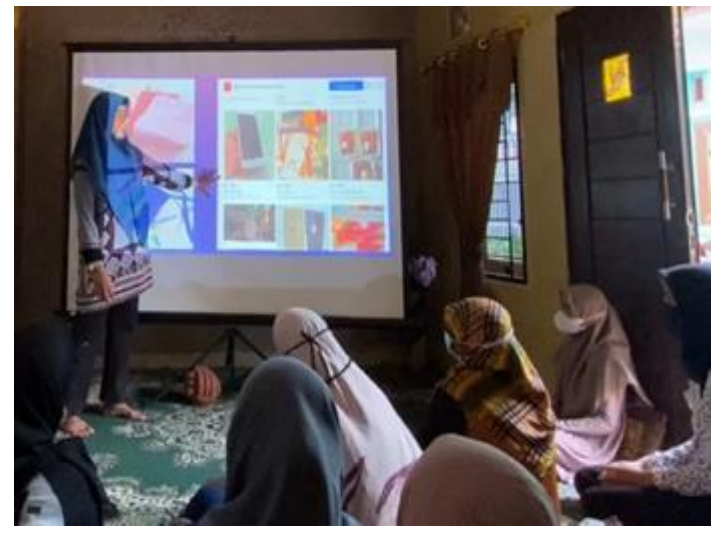

Gambar 1. Pelatihan tentang bisnis

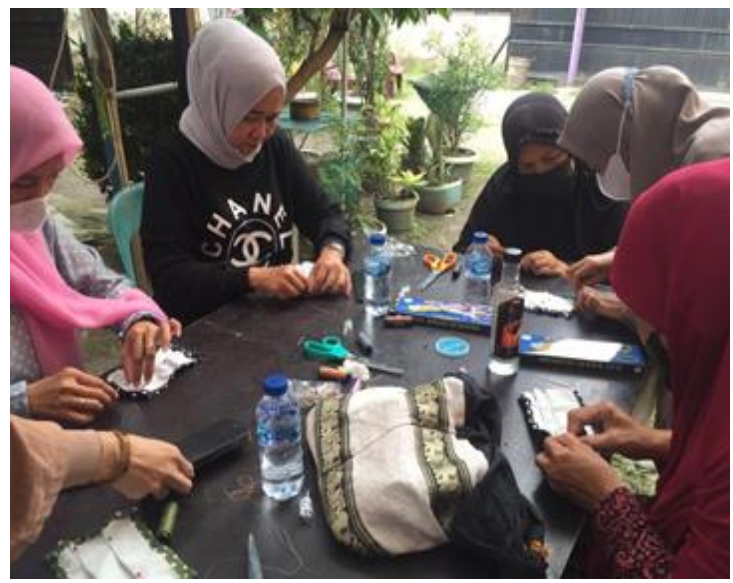

Gambar 3. Pelatihan Membuat masker kain

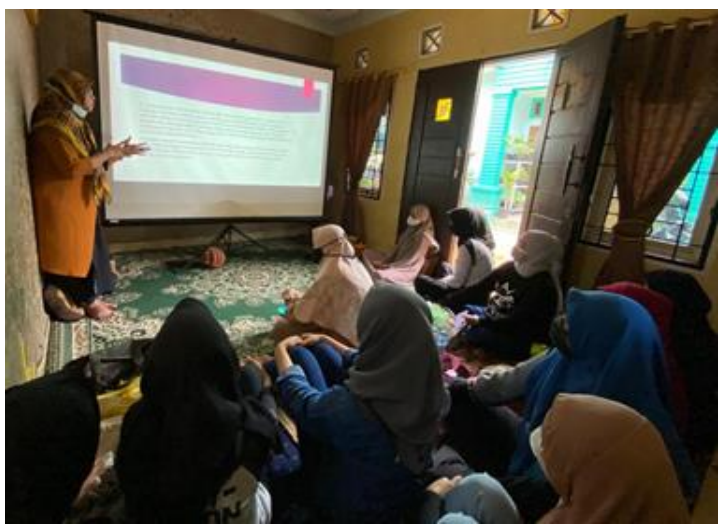

Gambar 2. Pelatihan Motivasi dan kreativitas

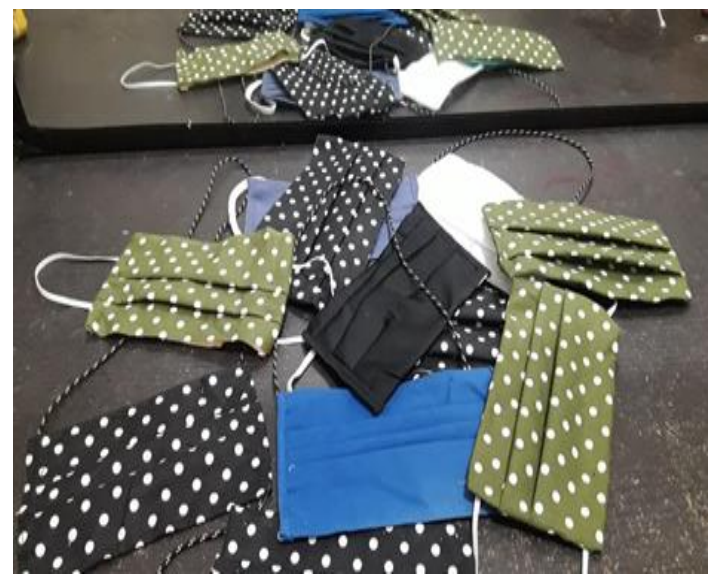

Gambar 4. Hasil Pembuatan masker kain

PKMS yang dilakukan memberikan dampak yang sangat baik bagi mitra, hal ini dibuktikan dari hasil penilaian melalui kuisioner. Mitra merasa sangat senang terhadap kegiatan yang dilakukan. Berdasarkan hasil wawancara dengan ketua kelompok, beliau menyatakan bahwa terjadi peningkatan motivasi diri, peningkatan pengetahuan, keahlian dan mendapatkan income tambahan. Para orang tua murid lebih kreatif dengan kemampuan yang dimiliki dan bisa menyalurkan hobby menggunakan media sosial.

Berdasarkan Gambar 8 diperoleh bahwa program ini menambah pengetahuan mitra sebanyak 70\% , keterampilan bertambah $70 \%$, income bertambah $10 \%$ motivasi dan kreatifitas meningkat $50 \%$ dan yang menyatakan kesejahteraan hidup meningkat sebanyak 30\%. 


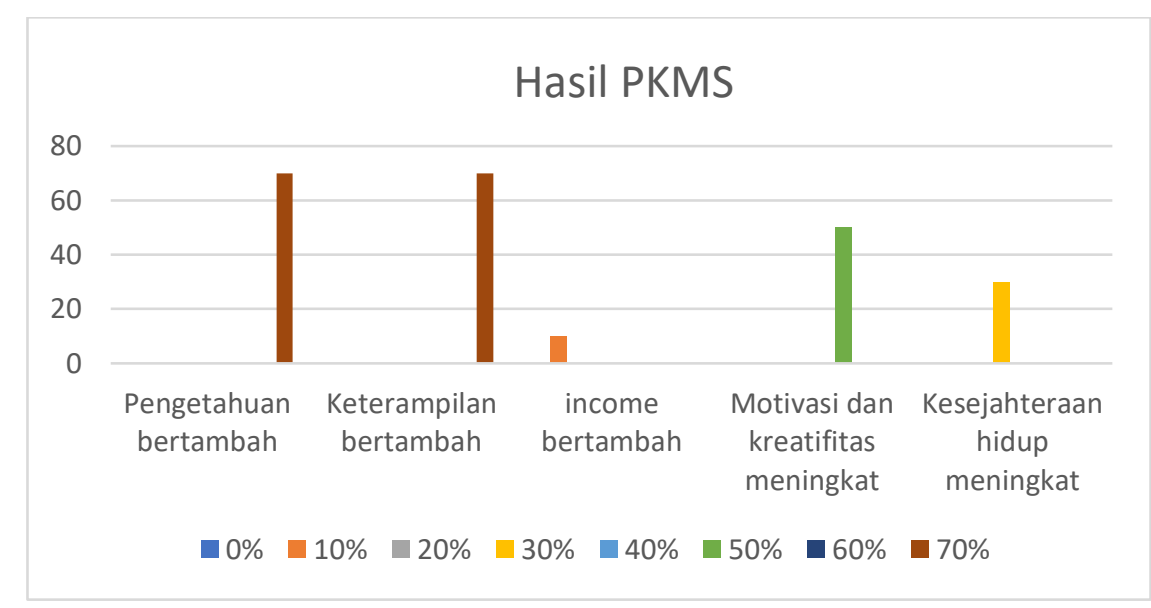

Gambar 5. Hasil PKMS terhadap Mitra

\section{KESIMPULAN}

Dari Pelaksanaan PKMS yang dilakukan pada mitra kesimpulannya adalah kegiatan ini berdampak pada meningkatnya pengetahuan, keterampilan serta pendapatan ibu-ibu orangtua murid. Pelatihan juga berfokus pada pembuatan masker kain dan penjualan hasil kerajinan menggunakan media sosial. Mitra diharapkan bisa meningkatkan kreatifitas dalam membuat bermacam bentuk masker dan memanfaatkan media sosial secara bijak terutama untuk berbisnis.

\section{UCAPAN TERIMA KASIH}

Dalam Pengabdian ini tim Pengabdi mengucapkan terikasih yang sebesar-besarnya kepada :

1. Direktorat Riset dan Pengabdian Masyarakat yang telah mendanai pelaksanaan program pengabdian ini.

2. LLDIKTI 1 Sumatera Utara yang telah mengkoordinir dan memfasilitasi pelaksanaan Pengabdian kepada Masyarakat ini.

3. LPPM Politeknik LP3I Medan yang telah mengkoordinir terlaksananya program Pengabdian Kepada Masyarakat

4. Ketua Kelompok Ibu-ibu orangtua Murid SD Muhammadiyah 28 Pulo Brayan Medan

\section{DAFTAR PUSTAKA}

Ansori, M. H. (2020). Wabah covid-19 dan kelas sosial di Indonesia. THC Insights.

Hanoatubun, S. (2020). Dampak Covid-19 Terhadap perekonomian Indonesia. EduPsyCouns, vol 2 no 1.

Laelisneni, d. (2020). Metode peningkatan produktivitas ekonomi orantua murid taman kanak-kanak melalui program PKMS. Teknovasi, vol 7 no 1.

Prstiana, d. (2009). Faktor-faktor yang mempengaruhi pengambilan keputusan wanita berusaha. Jurnal riset Ekonomi dan Bisnis, vol 9 no 1.

Sari, D. A. (2021). Kesiapan Ibu bermain bersama anak selama pandemi covid-19. Jurnal Obsesi , volume 5 issue 1.

Siagian, Y. (2021). Pelatihan penggunaan E-Commerce sebagai upaya pemasaran penjualan produk kerajinan rumah tangga ibu-ibu PKK. Journal of Social responsibility projects by higher Education forum, 25-30.

T.N.I, Z. (2020). Summary for policymakers in intergovermental panel on climate change. Cambridge University press. 